Atmos. Chem. Phys., 10, 9689-9704, 2010

www.atmos-chem-phys.net/10/9689/2010/

doi:10.5194/acp-10-9689-2010

(C) Author(s) 2010. CC Attribution 3.0 License.

\title{
Arctic shipping emissions inventories and future scenarios
}

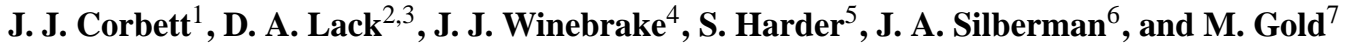 \\ ${ }^{1}$ College of Earth, Ocean, and Atmosphere, University of Delaware, Newark, DE, 19716, USA \\ ${ }^{2}$ NOAA Earth System Research Laboratory, Boulder, CO, 80305, USA \\ ${ }^{3}$ Cooperative Institute for Research in Environmental Sciences, University of Colorado, Boulder, CO, 80309, USA \\ ${ }^{4}$ Rochester Institute of Technology, Rochester, 14623, NY, USA \\ ${ }^{5}$ Transport Canada, Vancouver, British Columbia, V6Z 2J8, Canada \\ ${ }^{6}$ GIS Consulting, Unionville, PA, 19375, USA \\ ${ }^{7}$ Canadian Coast Guard, Ottawa, Ontario, K1A 0E6, Canada
}

Received: 29 March 2010 - Published in Atmos. Chem. Phys. Discuss.: 19 April 2010

Revised: 29 September 2010 - Accepted: 4 October 2010 - Published: 14 October 2010

\begin{abstract}
This paper presents $5 \mathrm{~km} \times 5 \mathrm{~km}$ Arctic emissions inventories of important greenhouse gases, black carbon and other pollutants under existing and future (2050) scenarios that account for growth of shipping in the region, potential diversion traffic through emerging routes, and possible emissions control measures. These high-resolution, geospatial emissions inventories for shipping can be used to evaluate Arctic climate sensitivity to black carbon (a short-lived climate forcing pollutant especially effective in accelerating the melting of ice and snow), aerosols, and gaseous emissions including carbon dioxide. We quantify ship emissions scenarios which are expected to increase as declining sea ice coverage due to climate change allows for increased shipping activity in the Arctic. A first-order calculation of global warming potential due to 2030 emissions in the highgrowth scenario suggests that short-lived forcing of $\sim 4.5$ gigagrams of black carbon from Arctic shipping may increase global warming potential due to Arctic ships' $\mathrm{CO}_{2}$ emissions ( $\sim 2000$ gigagrams) by some $17 \%$ to $78 \%$. The paper also presents maximum feasible reduction scenarios for black carbon in particular. These emissions reduction scenarios will enable scientists and policymakers to evaluate the efficacy and benefits of technological controls for black carbon, and other pollutants from ships.
\end{abstract}

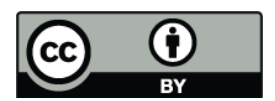

Correspondence to: J. J. Corbett (jcorbett@udel.edu)

\section{Introduction}

Dramatic decline of Arctic sea ice has been observed over the past few decades, culminating in a record minimum sea ice extent of 4.28 million $\mathrm{km}^{2}$ in 2007 ( $\sim 10$ million in 1970) (NSIDC, 2007). This decline in Arctic sea ice has re-ignited interest in efforts to establish new trade passages, raising the possibility of economically viable trans-Arctic shipping as well as increasing access to regional resources and spurring growth in localized shipping supporting natural resource extraction and tourism (ACIA, 2004; Jakobson, 2010; Westcott, 2007). Although increased Arctic shipping may provide commercial and social development opportunities, the associated increased environmental burdens are also of concern.

Studies assessing the potential impacts of international shipping on climate and air pollution demonstrate that ships contribute significantly to global climate change and health impacts through emission of greenhouse gases (GHGs) and other pollutants (e.g., carbon dioxide $\left[\mathrm{CO}_{2}\right]$, methane $\left[\mathrm{CH}_{4}\right]$, nitrogen oxides $\left[\mathrm{NO}_{\mathrm{x}}\right]$, sulfur oxides $\left[\mathrm{SO}_{\mathrm{x}}\right]$, carbon monoxide $[\mathrm{CO}]$, and various species of particulate matter $[\mathrm{PM}]$ including organic carbon $[\mathrm{OC}]$ and black carbon $[\mathrm{BC}])(\mathrm{Ca}-$ paldo et al., 1999; Corbett et al., 2007; Fuglestvedt et al., 2008, 2009; Lauer et al., 2009; Winebrake et al., 2009b). Although at present in-Arctic ship emissions make up a relatively small proportion of global shipping emissions, there are region-specific effects from substances such as BC and ozone $\left(\mathrm{O}_{3}\right)$ which are becoming increasingly important to quantify and understand.

Most significant for the Arctic is the additional source of short-lived climate forcing agents (such as $\mathrm{BC}, \mathrm{CH}_{4}$, and $\mathrm{O}_{3}$ ) from ships in proximal transport distance (within a few

Published by Copernicus Publications on behalf of the European Geosciences Union. 
hundred kilometers); Arctic impacts from regional shipping may compare with long-range transport of larger emissions sources from lower latitude biomass and fossil fuel combustion. The recent Tromso Declaration of the Arctic Council, Ministers highlighted this issue by specifically calling out the important role that shorter-lived forcers play in Arctic climate change and recognizing that reducing these shorterlived pollutants can reduce near-term climate change impacts such as snow, sea ice, and sheet ice melting (Arctic Council, 2009a).

Current estimates (for the year 2007) report that international shipping emits about $1000 \mathrm{Tg} \mathrm{CO}_{2} / \mathrm{y}$, with projected increases attributed to growth in international trade (Buhaug et al., 2009). Black carbon, a component of PM produced by marine vessels through the incomplete oxidation of carbon in diesel cycles, has a positive climate-forcing effect since it absorbs sunlight (Flanner et al., 2007; Reddy and Boucher, 2006). This effect is likely greater in the Arctic region and other snow- and ice-covered regions, because atmospheric BC layers absorb radiation both from incident sunlight and sunlight reflected from the surface. Also, when deposited to the snow or ice surface, $\mathrm{BC}$ can reduce surface reflectivity (i.e., albedo), accelerating the melting process (Flanner et al., 2007, 2009; Hansen and Nazarenko, 2004; Hansen et al., 2005).

International shipping emits between 71000 and 160000 metric tons (mt) of BC annually, representing about $15 \%$ of total PM emitted by ships and about $\sim 2 \%$ of global BC from all sources (Corbett et al., 2007; Lack et al., 2008, 2009). Uncertainties are currently driven by confidence bounds on emissions rates for BC. The total nearterm warming impact of global $\mathrm{BC}$ emissions from global sources has been estimated to range between $18 \%$ and $55 \%$ of global $\mathrm{CO}_{2}$ forcing. This percentage is greater than forcing from $\mathrm{CH}_{4}, \mathrm{CFCs}, \mathrm{N}_{2} \mathrm{O}$ or tropospheric $\mathrm{O}_{3}$ (Ramanathan and Carmichael, 2008). The total climate forcing impacts attributable to $\mathrm{BC}$ from ships have not been estimated independent of other PM impacts (IPCC, 2007; Ramanathan and Carmichael, 2008).

To better understand the potential impact of Arctic ship emissions on the climate, scientists and modelers require high-resolution geospatial emissions inventories suitable for regional-scale evaluation. This paper presents such inventories for emissions of $\mathrm{BC}, \mathrm{OC}, \mathrm{PM}, \mathrm{NO}_{\mathrm{x}}, \mathrm{SO}_{\mathrm{x}}, \mathrm{CO}$ and $\mathrm{CO}_{2}$. We produce future inventory scenarios for in-Arctic shipping that includes growth, emissions changes through current legislation, and potential access of navigable routes for diversion traffic to provide insights into current and future impacts. Lastly, we provide maximum feasible reduction (MFR) scenarios aimed at reducing short-lived forcing impacts of $\mathrm{BC}$.

\section{Estimating geospatially resolved emissions from in-Arctic shipping}

Empirical data of shipping activity reported by Arctic Council member states is used to produce a present-day (2004) Arctic emissions inventory (Arctic Council, 2009b). This inventory methodology employs the most recent estimates of PM emission factors and an activity-based approach that is the state-of-practice for ship inventories, tailored for Arctic shipping as described in the Arctic Marine Shipping Assessment 2009 (the AMSA) report (Arctic Council, 2009b). Emissions are calculated for each vessel-trip for which data were available for the base year 2004. Future seasonal emissions are projected under high-growth and business as usual (BAU) assumptions and adopted future regulations. Emissions from trans-Arctic navigation routes are also projected with emissions assuming 1\%,2\%, and 5\% diversion of global shipping for 2020, 2030, and 2050, respectively.

\subsection{Route identification}

The AMSA database provides the geographical area that is the basis for the calculation of emission totals in this work. AMSA nations provided input on seasonal- and routespecific activity, from which vessel-specific routes were constructed and evaluated. Details of collection and GIS representation of shipping data from all Arctic states, representing "the first comprehensive Arctic vessel activity database for a given calendar year," are described in the Current Marine Use and the AMSA Shipping Database of the AMSA report (Arctic Council, 2009b). The data included: (1) vessel characteristics (ship identification number, vessel size, vessel type, main engine power, design speed); (2) trip data (duration, distance, origin port, destination port); and (3) geospatial information (latitude and longitude values for ship movements, where available). We use data provided by AMSA nations and used in the AMSA analysis, which cover the extent of the Arctic as "defined according to the internal policies among Arctic Council member states" (Arctic Council, 2009b). The AMSA data included a range of assumptions and limitations, but represents the best data available to date. Listed in Table 1 are ship types from the AMSA, with route counts for each type of ship. These vessel trips were mapped to the season in which they occurred, also shown in Table 1.

\subsection{Vessel characterization}

Different vessel types have variable emissions and thus an assessment of vessel characterization was performed for activity in Arctic waters (Arctic Council, 2009b). Recent work by Norwegian researchers at Det Norske Veritas (DNV) suggests that the AMSA assumptions for most ship types were valid, except that general cargo ships for Arctic operations have less installed power than globally typical. Based on comparisons with (DNV) data for these vessel types (Mjelde 
Table 1. 2004 Ship traffic by type and season reported by the Arctic marine shipping assessment (Arctic Council, 2009b).

\begin{tabular}{llll}
\hline Ship Type & Annual Trips & Season & Seasonal Trips \\
\hline Bulk Trips & 1052 & Winter (December-February) & 3072 \\
Container Trips & 2096 & & \\
General Cargo Trips & 1403 & Spring (March-May) & 3390 \\
Government Vessel Trips & 273 & & \\
OSV Trips & 58 & Summer (June-August) & 4807 \\
Passenger Vessel Trips & 6972 & & \\
Tanker Trips & 2827 & Fall (September-November) & 3729 \\
Tug and Barge Trips & 317 & & 14998 \\
Total Trips in 2004 & 14998 & & 149 \\
\hline
\end{tabular}

Note: Container trips include portions of transoceanic voyages that transected the study region; voyages for most other ship-types are contained within the study domain.

and Hustad, 2009), general cargo ship characteristics were modified downward for this inventory to conform better to empirical data for Arctic activity of these vessels.

Given the focus on transport vessels in this work, fishing vessel emissions are not provided geospatially in this study, but can be provided in future work. Moreover, a modified methodology to include fishing vessel emissions is required. Because fishing vessels do not travel along a defined course but drift across areas in search of catch, AMSA fishing vessel data is depicted by area as opposed to routes. Fishing vessel emissions estimated in the AMSA were based on the number of days operating underway associated with large marine ecosystems (LME) or fishing areas, instead of number of trips (Arctic Council, 2009b). It is important to note that for the AMSA study fishing vessels constituted a significant portion of all vessel traffic in the Arctic regions, making up more than half of all vessels reported (Arctic Council, 2009b). Moreover, activity-based emissions are computed slightly differently and the scenario(s) in which fishing activity may change over the next decades would require different assumptions than scenarios for transport vessels.

\subsection{Emissions Factor (EF) determination}

Combustion PM is a general term representing a composite of primary particles formed during combustion processes and/or secondary particles formed via exhaust gas chemistry (Eyring et al., 2010; Lack et al., 2008, 2009; Robinson et al., 2007). Particulate matter species generally associated with combustion of heavy fuel oils (HFO) in marine diesel engines include $\mathrm{BC}, \mathrm{OC}$, sulfur aerosols, ash, and trace metals, among others. Particulate matter speciation is primarily a function of fuel quality and consumed cylinder lubricants, while their size and number depends mostly upon combustion conditions. For future scenarios, legislation to reduce sulfur content in marine fuels and control $\mathrm{NO}_{\mathrm{x}}$ emissions rates will, in turn, affect fuel-quality and lubricant emissions of organic carbon (International Maritime Organization, 2008).
The BC fraction of PM observed in marine engine exhaust has been investigated in both stack exhaust and atmospheric plume studies (Lack et al., 2008, 2009; Moldanová et al., 2009; Petzold et al., 2008), and has been variously reported to range from less than $5 \%$ to more than $40 \%$ on a mass basis (Bond et al., 2004; Lack et al., 2009; Lyyranen et al., 1999; Moldanová et al., 2009). The Second International Maritime Organization (IMO) GHG Study 2009 reported that BC contributed about $5.1 \%$ to total PM mass, partly due to inclusion of water mass associated with sulfate (Buhaug et al., 2009). Lack et al. (2009) and Bond et al. (2004) report central values of approximately $15 \%$ and $8 \%$, respectively, on a dry particle basis. Importantly, a large number of fine particles from high-temperature, high-pressure combustion is typical of marine diesel engine combustion, and the $\mathrm{BC}$ mass variability is statistically independent of correlated changes in fuel-sulfur content and OC emissions (Lack et al., 2009).

The emission factors (EFs) used here for $\mathrm{BC}, \mathrm{OC}$, and sulfur emissions $\left(\mathrm{SO}_{\mathrm{x}}\right.$ as $\left.\mathrm{SO}_{2}\right)$ are from the IMO Study (Buhaug et al., 2009), with additional speciation of PM to provide emissions factors for $\mathrm{BC}$ and $\mathrm{OC}$ based on literature (Lack et al., 2008, 2009). Future EFs generally follow the IMO Study (Buhaug et al., 2009) reporting changes in $\mathrm{SO}_{\mathrm{x}}$ and $\mathrm{NO}_{\mathrm{x}}$ due to IMO legislation to be implemented by 2020, with two exceptions. We adjusted future EFs to reflect Annex VI emissions controls of $\mathrm{SO}_{\mathrm{x}}$ from the current world average (about $2.7 \%$ ) to $0.5 \%$ (International Maritime Organization, 2008). Recent field measurement campaigns observed that BC EFs are statistically unchanged by lower-sulfur fuels whereas OC and $\mathrm{SO}_{\mathrm{x}}$ EFs are correlated (Lack et al., 2008, 2009). Therefore, we apply an emission rate for $\mathrm{BC}$ of $0.35 \mathrm{~g} / \mathrm{kg}$ fuel and a rate for $\mathrm{OC}$ that varies proportionally with a sulfur content range of $2.7 \%$ to $0.5 \%$. We recognize that reported standard deviations on the many observations in Lack et al. (2008; 2009) are large, and capture reported point estimates from other studies of individual engines.

Table 2 presents these emissions factors in units of grams pollutant per kilogram fuel, consistent with the Second IMO GHG study (Buhaug et al., 2009) and published studies 
Table 2. Gas and PM emission factors applied to current and future Arctic shipping (g/kg fuel $)^{1}$.

\begin{tabular}{|c|c|c|c|c|c|}
\hline & Ship Type & $2004 \mathrm{EFs}$ & $2020 \mathrm{EFs}$ & $2030 \mathrm{EFs}$ & $2050 \mathrm{EFs}$ \\
\hline $\mathrm{CO}$ & All & 7.4 & 7.4 & 7.4 & 7.4 \\
\hline \multirow[t]{2}{*}{$\mathrm{NO}_{\mathrm{x}}$} & Transport & 78 & 67 & 56 & 56 \\
\hline & Fishing vessels ${ }^{2}$ & 56 & 56 & 56 & 56 \\
\hline \multirow[t]{2}{*}{ PM } & Transport & 5.3 & 1.4 & 1.4 & 1.4 \\
\hline & Fishing vessels ${ }^{2}$ & 1.1 & 1.1 & 1.1 & 1.1 \\
\hline \multirow[t]{2}{*}{$\mathrm{SO}_{\mathrm{x}}$} & Transport & 54 & 10 & 10 & 10 \\
\hline & Fishing vessels ${ }^{2}$ & 10 & 10 & 10 & 10 \\
\hline \multirow[t]{2}{*}{$\mathrm{CO}_{2}$} & Transport & 3206 & 3206 & 3206 & 3206 \\
\hline & Fishing vessels ${ }^{2}$ & 3114 & 3114 & 3114 & 3114 \\
\hline $\mathrm{BC}$ & All & 0.35 & 0.35 & 0.35 & 0.35 \\
\hline $\mathrm{OC}$ & All & 1.07 & 0.39 & 0.39 & 0.39 \\
\hline
\end{tabular}

${ }^{1}$ Based on IMO Study (Buhaug et al., 2009) and Lack et al. (2008, 2009); future EFs reflect current legislation implementation schedules.

2 Fishing emissions rates provided for comparison; estimates included totals even though spatial processing of fishing emissions is not included here.

Table 3. In-Arctic shipping emissions estimates by vessel type $2004(\mathrm{mt} / \mathrm{y})^{1}$

\begin{tabular}{llllllll}
\hline Vessel Category & $\mathrm{CO}_{2}(000 \mathrm{mt} / \mathrm{y})$ & $\mathrm{BC}(\mathrm{mt} / \mathrm{y})$ & $\mathrm{OC}(\mathrm{mt} / \mathrm{y})$ & $\mathrm{SO}_{\mathrm{x}}(\mathrm{mt} / \mathrm{y})$ & $\mathrm{NO}_{\mathrm{x}}(\mathrm{mt} / \mathrm{y})$ & $\mathrm{PM}(\mathrm{mt} / \mathrm{y})$ & $\mathrm{CO}(\mathrm{mt} / \mathrm{y})$ \\
\hline Container Ship $^{2}$ & 2400 & 260 & 790 & 40000 & 58000 & 3900 & 5500 \\
General Cargo Ship & 2000 & 220 & 670 & 34000 & 49000 & 3300 & 4600 \\
Bulk Ships & 1200 & 130 & 410 & 21000 & 30000 & 2000 & 2800 \\
Passenger Vessels & 1100 & 120 & 380 & 19000 & 27000 & 1900 & 2600 \\
Tanker & 900 & 100 & 300 & 15000 & 22000 & 1500 & 2100 \\
Government Vessels & 380 & 40 & 130 & 6000 & 9000 & 630 & 880 \\
Tug and Barge & 40 & 4 & 12 & 600 & 863 & 59 & 82 \\
Offshore Service Vessel & 10 & 1 & 4 & 183 & 263 & 18 & 25 \\
Transit Total & 8000 & 880 & 2700 & 136000 & 196,000 & 13300 & 18600 \\
Fishing & 3200 & 350 & 1080 & 10000 & 58000 & 1100 & 7500 \\
In-Arctic Total (mt/y) $^{3}$ & 11200 & 1230 & 3780 & 146000 & 254000 & 14500 & 26100 \\
\hline
\end{tabular}

${ }^{1}$ Values are rounded to nearest $10 \mathrm{mt} / \mathrm{y}$, except for $\mathrm{CO}_{2}$ (rounded to $10000 \mathrm{mt} / \mathrm{y}$ ) and for values that would round to zero (rounded to integer); data sets reported in grams and not rounded.

2 Containership activity includes a portion of a transpacific route within the AMSA domain.

${ }^{3}$ Fishing vessel estimates reported in this table for comparison, but not provided within the Transport Vessel inventory reported here. Estimates for fishing vessels should be considered very uncertain.

${ }^{4}$ Total $\mathrm{CO}_{2}$ emissions (for example comparison) in the Arctic represent less than one percent of global $\mathrm{CO}_{2}$ from shipping as reported in Sect. 2.

(Cooper, 2004; Corbett and Koehler, 2003); these can be also reported in grams per kilowatt-hour $(\mathrm{g} / \mathrm{kWh})$ using typical specific fuel oil consumption rates as a conversion factor.

\subsection{Emissions estimation}

The activity-based model follows the general formula shown in Eq. (1):

$\mathrm{E}_{i j k}=\mathrm{EF}_{i j} \times \mathrm{LF}_{j k} \times \frac{\mathrm{KW}_{j}}{n_{j}} \times \mathrm{T}_{j k}$

where, $\mathrm{E}_{i j k}$ are emissions of type $i$ from vessel $j$ on route $k$ in grams $(\mathrm{g}) ; \mathrm{EF}_{i j}$ is the emissions factor for emissions of type $i$ on vessel $j$ in $\mathrm{g} / \mathrm{kwh} ; \mathrm{LF}_{j k}$ is the average engine load factor for vessel $j$ on route $k$ and takes into account peri- ods of maneuvering, slow cruise, and full cruise operations; $\mathrm{KW}_{j}$ is the rated main engine power in kilowatts for vessel $j ; \eta_{j}$ is the engine efficiency; and $\mathrm{T}_{j k}$ is the duration of the trip for vessel $j$ on route $k$ in hours (h). Load factors are similar to those used in many global and regional inventory estimates for shipping (Buhaug et al, 2009; Corbett and Koehler, 2003). Table 3 presents a total in-Arctic emissions summary (in $\mathrm{mt} / \mathrm{y}$ ) by vessel type for 2004 .

\subsection{Geospatial emissions profiles}

Arctic shipping routes, vessel characterization and EFs were combined to produce the geospatial emissions inventory. Data fields include longitude and latitude degrees for each grid cell at $5 \mathrm{~km}$ resolution, and emissions data in grams per 
Table 4. Seasonal emissions of in-Arctic ship traffic for 2004.

\begin{tabular}{llllllll}
\hline Seasonal Summary & $\mathrm{CO}_{2}(000 \mathrm{mt} / \mathrm{y})$ & $\mathrm{BC}(\mathrm{mt} / \mathrm{y})$ & $\mathrm{OC}(\mathrm{mt} / \mathrm{y})$ & $\mathrm{SO}_{\mathrm{x}}(\mathrm{mt} / \mathrm{y})$ & $\mathrm{NO}_{\mathrm{x}}(\mathrm{mt} / \mathrm{y})$ & $\mathrm{PM}(\mathrm{mt} / \mathrm{y})$ & $\mathrm{CO}(\mathrm{mt} / \mathrm{y})$ \\
\hline Winter & 1600 & 180 & 550 & 28000 & 39750 & 2675 & 3775 \\
Spring & 1800 & 190 & 600 & 30000 & 43350 & 2975 & 4075 \\
Summer & 2500 & 280 & 850 & 43000 & 61750 & 4175 & 5875 \\
Fall & 2100 & 230 & 700 & 35000 & 51150 & 3475 & 4875 \\
Annual Total (mt/y) & 8,000 & 880 & 2700 & 136000 & 196000 & 13300 & 18600 \\
\hline
\end{tabular}

Note: Estimates rounded before summing.

Table 5. Input growth rates by vessel type from scenario model used in IMO study (Buhaug et al., 2009).

\begin{tabular}{lllllll}
\hline & \multicolumn{2}{c}{2004 To 2020} & \multicolumn{2}{c}{2004 To 2030} & \multicolumn{2}{c}{2004 To 2050 } \\
\hline Vessel Category & BAU Growth & High-Growth & BAU Growth & High-Growth & BAU Growth & High-Growth \\
Container Ship & $2.98 \%$ & $4.77 \%$ & $3.42 \%$ & $5.05 \%$ & $3.82 \%$ & $5.38 \%$ \\
General Cargo Ship & $0.29 \%$ & $1.13 \%$ & $0.42 \%$ & $1.16 \%$ & $0.54 \%$ & $1.22 \%$ \\
Bulk Ships & $1.43 \%$ & $2.27 \%$ & $1.59 \%$ & $2.34 \%$ & $1.72 \%$ & $2.40 \%$ \\
Passenger Vessels & $0.68 \%$ & $1.53 \%$ & $0.84 \%$ & $1.58 \%$ & $0.99 \%$ & $1.66 \%$ \\
Tanker & $4.46 \%$ & $5.31 \%$ & $3.41 \%$ & $4.16 \%$ & $2.71 \%$ & $3.38 \%$ \\
Government Vessels & $-0.08 \%$ & $0.77 \%$ & $0.10 \%$ & $0.85 \%$ & $0.23 \%$ & $0.90 \%$ \\
Tug and Barge & $-0.08 \%$ & $0.77 \%$ & $0.10 \%$ & $0.85 \%$ & $0.23 \%$ & $0.90 \%$ \\
Offshore Service Vessel & $2.19 \%$ & $3.04 \%$ & $1.76 \%$ & $2.50 \%$ & $1.47 \%$ & $2.14 \%$ \\
\hline
\end{tabular}

Note: Growth rates use the same scenario model as the IMO GHG study (Buhaug et al., 2009).

cell for $\mathrm{BC}, \mathrm{OC}, \mathrm{PM}$, and $\mathrm{CO}$, and in kg per cell for $\mathrm{CO}_{2}$, $\mathrm{SO}_{\mathrm{x}}$ (as $\mathrm{SO}_{2}$ ), and $\mathrm{NO}_{\mathrm{x}}$ (as $\mathrm{NO}_{2}$ ). Both annual and seasonal data are provided. Seasonal representation of these data is shown in plates b) through e) in Fig. 1, alongside a polar projection of prior global inventory coverage of Arctic regions (Wang et al., 2008) (Fig. 1a), and a depiction of potential routes for diversion traffic if ice-free navigation becomes attractive in the future for shorter-voyage diversion of global shipping (Fig. 1f and discussed below).

The $5 \mathrm{~km} \times 5 \mathrm{~km}$ resolution is coarser than the original AMSA data used to generate the inventory but provides greater resolution than the maps produced by AMSA $(1: 30000000$ scale, where $1 \mathrm{~cm}=\sim 300 \mathrm{~km})$. As part of the GIS data processing, the Universal Polar Stereographic (UPS) projection coordinate system that covers regions above 84 degrees North with a central point at the North Pole was maintained; therefore potential additional distortion due to projection-conversion was minimized. Comparisons of emissions totals were accumulated to provide quality assurance on the processing results. Seasonal data provided gridded representations of Arctic shipping emissions that sum to the annual inventory totals (see Table 4) and indicated a post-processing cumulative error attributed to the conversion of data of $\sim \pm 1.3 \%$.

\subsection{In-Arctic future year scenarios}

In-Arctic shipping traffic is predicted to increase with increases in a variety of activities, including resource extraction, tourism and cargo transportation. Most forecasts of emissions in the shipping industry are allocated spatially by assuming homogeneous distribution among vessel types (Wang et al., 2008). However, the asymmetric growth in activity among ship types is well understood in terms of economics and trade, with vessel activity involved in moving containerized goods and energy products growing faster than other ship types. To date, only a few regional studies are considering spatial differences among different vessel types (Corbett et al., 2007; Dalsoren et al., 2007). The seasonal inventories of in-Arctic shipping by vessel type were grown independently using growth rates from the scenario model employed in the Second IMO GHG Study 2009 (Buhaug et al., 2009). We defined lower-growth rates to represent a business-as-usual (BAU) scenario and higher growth rates to represent a high-growth scenario for in-Arctic shipping (see Table 5). Growth rates are applied to activity-based emissions in scenarios initially assuming no emission controls; only with emissions controls aimed asymmetrically at one or more species are the relative changes among pollutant trends affected. With emission controls, these trends are adjusted specifically for each pollutant $\left(\mathrm{NO}_{\mathrm{x}}\right.$ and $\mathrm{SO}_{\mathrm{x}}$ under Annex VI policy intervention, $\mathrm{OC}$ as consequence of sulfur reductions, 

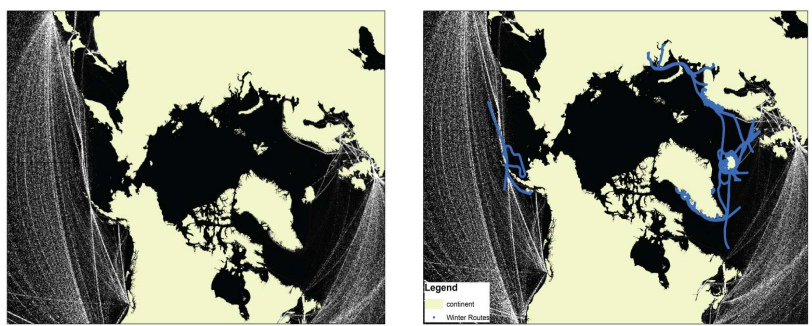

b)
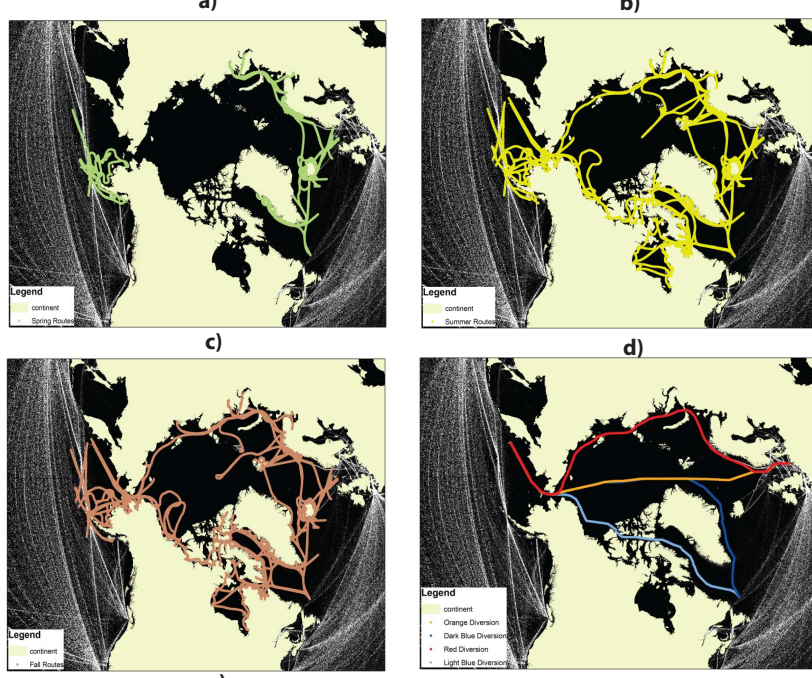

e) d)

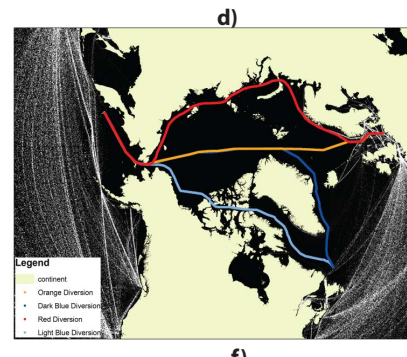

f)

Fig. 1. Summary of seasonal traffic patterns for in-Arctic shipping: (a) global data prior to this work; (b) winter shipping 2004; (c) spring shipping 2004; (d) summer shipping 2004; (e) fall shipping 2004; and (f) potential global shipping diversion routes given navigable routes for diversion traffic open in Arctic.

and BC through the MFR scenario emissions controls) discussed in Sect. 2.3.

The in-Arctic BAU scenario is closest to the base-case B1, B2, and A2 scenarios in the IMO Study (Buhaug et al., 2009). The in-Arctic high-growth scenario falls between the A1 base-case and high-growth scenarios, reflecting activity that may conform loosely either to the so-called Arctic Saga or Arctic Race scenarios (Arctic Council, 2009b; Buhaug et al., 2009). Arctic Saga and Arctic Race are described respectively by the AMSA Study (Arctic Council, 2009b) as "a healthy rate of Arctic development that includes concern for the preservation of Arctic ecosystems and cultures and shared economic and political interests," and a "lack of an integrated set of maritime rules and regulations, and insufficient infrastructure to support such a high level of marine activity." Therefore, the scenarios developed here (a) produce future shipping patterns where changes in routes are dominated by growth in one or a few vessel types and (b) should be valuable for impact assessment by scientists that produce results relevant for policy decision-making regarding the sensitive Arctic region.

\subsection{Diversion through Arctic future year scenarios}

Dramatic decline in Arctic sea ice extent over the past few years has raised the possibility of regular Arctic traffic diverted from current shipping routes (diversion traffic) producing both economic enthusiasm and environmental concern. Distance savings of $\sim 25 \%$ and $\sim 50 \%$ (and coincident time and fuel savings) are estimated for the Northwest Passage (NWP) and Northeast Passage (NEP), respectively. Commercial NWP transits between Japan, and Eastern Canada are estimated to be financially viable, although how much is debated (Somanathan et al., 2009). Commercial NEP transits between Shanghai and Hamburg are currently viable, yet double the cost of the traditional route (Verny and Grigentin, 2009).

Representing the potential emissions from these diversion routes even with the uncertainty in future diversion route viability is an important input to allow for prospective scientific assessment, to evaluate impact mitigation options and costs, and to inform good policy decisions. Therefore we construct four potential diversion routes, depicted in Fig. 1f, including the NEP, NWP and two polar routes. These routes are selected based on current Arctic shipping lanes (see Fig. 1bf) and predictions of likely polar routes from other studies (Arctic Council, 2009b). Existing routes along the Canadian Arctic coastline are not really NWP routes but depict local service; therefore, we defined the potential NWP route to represent a shorter transit path enabled by receding ice extent, at least seasonally.

We produce Arctic diversion inventories for potential opening of routes diverting current global ship traffic by the following process:

1. We assume annual growth in global shipping (from 2004 ) to be $3.3 \%$ per year (a central value between the IMO base case and high-growth scenarios);

2. An assessment of drivers toward diversion timing and quantity was made by assessing current literature regarding the feasibility of Arctic shipping (see initial discussion in Sect. 2.7) and shipping volumes through the Suez and Panama Canals ( $\sim 4 \%$ and $\sim 8 \%$ of global trade volume, respectively (Egyptian Maritime Data Bank, 2010; Panama Canal Operations, 2010)). These two statistics give an indicator of shipping volume attracted by global shipping "shortcuts".

3. Acknowledging uncertainty as to when diversion traffic may emerge, we chose to scale the percent diversion beginning in 2020 at $1 \%$ of global shipping, increasing to $2 \%$ in 2030 , and increasing to $5 \%$ in 2050 . 


\subsection{Maximum feasible reductions}

Future Arctic emissions may be targeted for reductions via a number of pathways including the expected global fuel quality regulations to be introduced through the MARPOL Annex VI legislation. Technologies may be employed, individually or in combinations, to achieve further controls; these include seawater scrubbing, slide valves, water-in-fuel emulsions, diesel particulate filters, and emissions scrubbing technologies. The MARPOL Annex VI legislation will mostly address $\mathrm{SO}_{2}$ and particulate sulfate emissions, with some associated OM reductions (Lack et al., 2009). BC emissions may benefit from MARPOL Annex VI legislation because some technically feasible $\mathrm{BC}$ controls require lower sulfur marine fuels and related changes in lubricating oil properties.

For this work, we assume the fleet wide maximum feasible reduction (MFR) for $\mathrm{BC}$ is $70 \%$, representing a combination technology performance (Winebrake et al., 2009a), and/or reasonable advances in single-technology performance. Not all technologies work equally well on BC particles as their efficacy rates for PM overall. For example, reported control efficiencies and principles of seawater scrubbing suggest that $\mathrm{BC}$ is controlled less effectively by current scrubbing technologies. Published studies of seawater scrubber performance report control efficiencies for PM in the range of $25-80 \%$, suggesting that volatile and semi-volatile particles are effectively adsorbed (Kircher, 2008; Winebrake et al., 2009a). While many studies do not report species-specific PM reductions, very small particles like BC are reported to be less controlled than larger ones. Moreover, hot-gaseous sulfur absorption at the seawater droplet surface is enhanced by chemical reactions with seawater alkaline species (Caiazzo et al., 2009). One seawater scrubbing trial on an auxiliary engine using HFO measured $98 \%$ reductions in $\mathrm{PM}_{2}$, $74 \%$ reductions in $\mathrm{PM}_{1.5}, 59 \%$ reductions in $\mathrm{PM}_{1}$, and $45 \%$ reductions in $\mathrm{PM}_{0.05}$ (Entec UK Limited et al., 2005). A December 2009 unpublished study undertaken by Sustainable Maritime Solutions Inc. and Ricardo Inc. (UK) indicate $55-70 \%$ reductions in $\mathrm{BC}$ mass using sea-water scrubbing technology (D. Gregory, personal communication, 2010). In other words, achieving 70\% MFR goals for BC may require further scrubber demonstration. Notwithstanding the potential for a single technology to achieve $70 \%$ control, combinations of technologies such as fuel-emulsions, in-engine modifications, and further sulfur removal in the fuels or exhaust can achieve MFR BC reductions along with reductions in other PM.

\section{Results}

\subsection{In-Arctic shipping}

The Arctic is sensitive to change and impacts, attributed to climate change, are already emerging. The emissions inventory derived from year-2004 reported shipping activity can help to assess the role shipping may play in present and future impacts. Total in-Arctic emissions are presented in Table 3. A comparison with prior estimates for the AMSA study reveals a key differences being the emissions for general cargo ships. Auxiliary engines for in-Arctic ships are not explicitly estimated, but the in-service fraction of installed auxiliary engine power is typically a small fraction of main engine power. Comparison of in-Arctic emissions by shiptype for the Norwegian data with a DNV report showed that all transport vessel inventories reported here are within $10 \%$ to $20 \%$ of the DNV estimates for vessels in this study. Assuming similarity among Arctic shipping reported by other nations, this agreement is considered to be strong for transport ship emissions described by these data.

Seasonal emissions of Arctic shipping for 2004 (Table 4) are dominated by Summer and Fall activity, with Winter and Spring being comparable and $\sim 30 \%$ lower than the other seasons. However, the total vessel trips within Fall, Winter and Spring vary little, indicating a shift in the vessel mix across seasons.

This vessel mix becomes evident by assessing the 2004 Arctic shipping composite regional growth rates for all shiptypes operating in Arctic waters produced by the emissions model. Table 6 shows these composite growth rates for $\mathrm{BC}$, $\mathrm{OC}, \mathrm{PM}, \mathrm{SO}_{\mathrm{x}}, \mathrm{NO}_{\mathrm{x}}, \mathrm{CO}$ and $\mathrm{CO}_{2}$ emissions. These growth rates differ from other forecasts for Arctic shipping but are more consistent than contradicting. For example, Dalsøren et al. (2007) estimate some $3.8 \mathrm{Tg} \mathrm{CO}_{2}$ in 2000 , forecasting growth in 2015 to as much as $4.9 \mathrm{Tg} \mathrm{CO}_{2}$ - a growth rate of $\sim 1.8 \%$ per year. Given that Dalsøren et al. (2007) mainly focuses on Norwegian coastal shipping dominated by oil transport (see their Tables 1 and 4), and that the scenario model produced a high-scenario growth rate for tankers of less than $2 \%$ per year, this close agreement in growth rates demonstrates consistency among the scenario model and others' work at national scales. Given that this work considers more vessel types and higher growth rates, these differences are expected.

Shipping patterns vary geospatially over time as illustrated in Fig. 2. This is a function of the asymmetric growth patterns produce by different vessel-specific growth rates, and results in a shift in the contribution to total emissions among ship types as shown in Table 7. Worth noting is that fishing vessels (not represented geospatially here) contribute proportionally less to future emissions under the assumed constancy in fish stocks and corresponding fishing-vessel activity. Given the conservatively high estimate for fishing vessel emissions by the AMSA study (reported above to be a factor 
Table 6. Regional growth rates resulting from vessel-specific growth rates.

\begin{tabular}{llllll}
\hline & $\mathrm{CO}_{2}, \mathrm{BC}, \mathrm{CO}(\Delta / \mathrm{y})$ & $\mathrm{OC}(\Delta / \mathrm{y})$ & $\mathrm{SO}_{\mathrm{x}}(\Delta / \mathrm{y})$ & $\mathrm{NO}_{\mathrm{x}}(\Delta / \mathrm{y})$ & $\mathrm{PM}(\Delta / \mathrm{y})$ \\
\hline BAU 2004-2020 & $1.96 \%$ & $-4.25 \%$ & $-8.24 \%$ & $1.03 \%$ & $-6.37 \%$ \\
High-Growth 2004-2020 & $3.18 \%$ & $-3.18 \%$ & $-7.14 \%$ & $2.24 \%$ & $-5.25 \%$ \\
BAU 2004-2030 & $2.12 \%$ & $-1.76 \%$ & $-4.30 \%$ & $0.86 \%$ & $-3.10 \%$ \\
High-Growth 2004-2030 & $3.29 \%$ & $-0.63 \%$ & $-3.20 \%$ & $2.02 \%$ & $-1.98 \%$ \\
BAU 2004-2050 & $2.44 \%$ & $0.22 \%$ & $-4.30 \%$ & $0.86 \%$ & $-3.10 \%$ \\
High-Growth 2004-2050 & $3.69 \%$ & $1.45 \%$ & $-3.20 \%$ & $2.02 \%$ & $-1.98 \%$ \\
\hline
\end{tabular}

Note: Growth rates calculated using compound annual growth rate (CAGR) equation.

Table 7. In-Arctic shipping emissions by vessel type across future scenarios.

\begin{tabular}{|c|c|c|c|c|c|c|c|}
\hline $\begin{array}{l}\text { Vessel } \\
\text { Category }\end{array}$ & $\begin{array}{l}2004 \\
\text { Pct of Total }\end{array}$ & $\begin{array}{l}2020 \text { BAU } \\
\text { Pct of Total }\end{array}$ & $\begin{array}{l}2030 \text { BAU } \\
\text { Pct of Total }\end{array}$ & $\begin{array}{l}2050 \text { BAU } \\
\text { Pct of Total }\end{array}$ & $\begin{array}{l}2020 \text { High-G } \\
\text { Pct of Total }\end{array}$ & $\begin{array}{l}2030 \text { High-G } \\
\text { Pct of Total }\end{array}$ & $\begin{array}{l}2050 \text { High-G } \\
\text { Pct of Total }\end{array}$ \\
\hline $\begin{array}{l}\text { Container } \\
\text { Ship }\end{array}$ & $21 \%$ & $27 \%$ & $34 \%$ & $50 \%$ & $31 \%$ & $40 \%$ & $61 \%$ \\
\hline $\begin{array}{l}\text { General } \\
\text { Cargo Ship }\end{array}$ & $18 \%$ & $15 \%$ & $13 \%$ & $9 \%$ & $15 \%$ & $12 \%$ & $8 \%$ \\
\hline Bulk Ships & $11 \%$ & $11 \%$ & $11 \%$ & $10 \%$ & $11 \%$ & $10 \%$ & $8 \%$ \\
\hline $\begin{array}{l}\text { Passenger } \\
\text { Vessels }\end{array}$ & $10 \%$ & $9 \%$ & $8 \%$ & $6 \%$ & $9 \%$ & $8 \%$ & $5 \%$ \\
\hline Tanker & $8 \%$ & $13 \%$ & $13 \%$ & $11 \%$ & $13 \%$ & $12 \%$ & $9 \%$ \\
\hline $\begin{array}{l}\text { Government } \\
\text { Vessels }\end{array}$ & $3 \%$ & $3 \%$ & $2 \%$ & $2 \%$ & $3 \%$ & $2 \%$ & $1 \%$ \\
\hline $\begin{array}{l}\text { Tug and } \\
\text { Barge }\end{array}$ & $0 \%$ & $0 \%$ & $0 \%$ & $0 \%$ & $0 \%$ & $0 \%$ & $0 \%$ \\
\hline $\begin{array}{l}\text { Offshore Ser- } \\
\text { vice Vessel }\end{array}$ & $0 \%$ & $0 \%$ & $0 \%$ & $0 \%$ & $0 \%$ & $0 \%$ & $0 \%$ \\
\hline Transit Total & $71 \%$ & $77 \%$ & $81 \%$ & $88 \%$ & $80 \%$ & $85 \%$ & $93 \%$ \\
\hline Fishing $^{1}$ & $29 \%$ & $23 \%$ & $19 \%$ & $12 \%$ & $20 \%$ & $15 \%$ & $7 \%$ \\
\hline
\end{tabular}

${ }^{1}$ Relatice decline in fishing vessels and increase in transport vessels is attributed to growth scenarios by vessel type (see IMO study for discussion (Buhaug et al., 2009)) and negligible change in fish stocks assumed for this work.

of three greater than comparison with a Norwegian fishing inventory; Mjelde and Hustad, 2009), transport ships in the Arctic will remain the dominant contributor to in-Arctic marine vessel emissions.

Growth rates in energy use (as reflected by proportional increases in $\mathrm{CO}_{2}, \mathrm{BC}$, and $\mathrm{CO}$ ) are similar to IMO Study growth rates (Buhaug et al., 2009). Emissions are reported in Tables 8 and 9 for the BAU and high-growth scenarios, respectively.

\subsection{Potential diversion in ice-free seasons}

Table 10 presents pollutant inventories for future year projections of diversion traffic through the Arctic. The sum of 2050 in-Arctic and 5\% global diversion route emissions for the high-growth scenario result in a $\mathrm{NO}_{\mathrm{x}}$ estimate that compares very well with previous work (Granier et al., 2006); our estimated sum $\left(0.75 \mathrm{Tg} \mathrm{NO}_{\mathrm{x}}\right.$ in-Arctic plus $1.9 \mathrm{Tg} \mathrm{NO}_{\mathrm{x}}$ from diversions) results in $2.65 \mathrm{Tg}_{\mathrm{NO}}$ or $\sim 0.7 \mathrm{Tg} \mathrm{N}-$ within the range of 0.65 to $1.3 \mathrm{Tg} \mathrm{N}$ estimated by Granier et al. (2006). Under the BAU scenarios, and if trans-Arctic shipping does not emerge, expected impacts to regional ozone would be similar to work by Paxian et al. (2010). The scenarios reported here produce 2050 emissions $\sim 2-4$ times greater than Paxian et al. (2010) estimates (depending on which of their scenarios we compare), partly attributable to their focus on diversion traffic and our inclusion of in-Arctic traffic reported by the Arctic nations. A shipping traffic diversion rate of $\sim 1.8 \%$ and BAU in-Arctic rates would produce similar inventory totals estimated by Paxian et al. (2010). Differences may also be attributed to different inputs for emissions rates for some pollutants.

Diverted emissions are expected to be distributed during ice-free or navigable seasons spanning longer periods as Arctic ice melts and the diversion potential increases, as illustrated in Tables 11 and 12. The inventories provided can be 


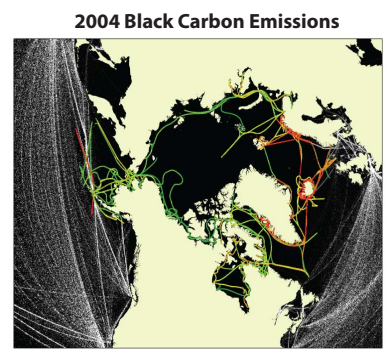

(a)

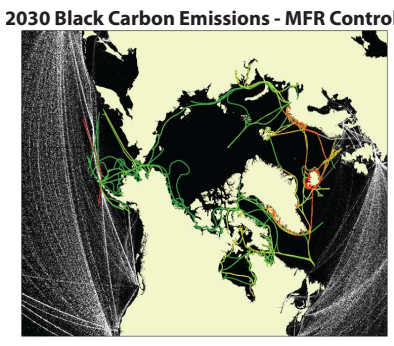

(c)

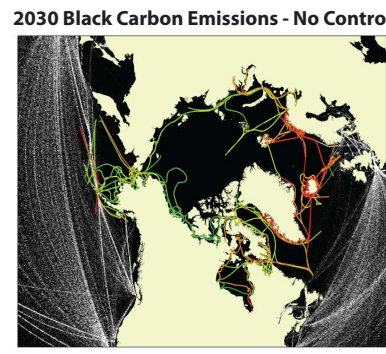

(b)

\section{BC (g per $5 \mathrm{~km}$ grid) \\ - $2-535$ \\ $536-1,267$ \\ $1,268-3,209$ \\ $3,210-8,981$ \\ - $8,982-997,817$}

Emissions Scale
Fig. 2. Illustration of (a) 2004 black carbon emissions; (b) 2030 projections for black carbon; (c) 2030 black carbon with MFR controls.

allocated by modelers and policy analysts to explore additional diversion scenarios, based on updated predictions of route navigability and economic incentive to assign ships to one or more of these routes.

\section{Discussion}

The future scenarios for shipping emissions (both in-Arctic and global) provide asymmetric trends among pollutants due to a combination of current legislation implementation for some pollutants, efficiencies in new technologies, and expected growth in shipping activity driven by economic opportunities. The net effect of these drivers on in-Arctic shipping (not including potential diversion routes) is embedded in the inventory scenarios reported here as illustrated by the annual trends in Fig. 3. For both high-growth and BAU scenarios, the IMO legislation to reduce fuel-sulfur emissions will reduce $\mathrm{SO}_{\mathrm{x}}$ emissions substantially between now and 2020 (International Maritime Organization, 2008). Coincident with that will be reductions in OC, due primarily to fuel and lubricating oil changes driven by lower-sulfur fuels. Black carbon emissions are expected to increase without control requirements, along with $\mathrm{CO}_{2} ; \mathrm{NO}_{\mathrm{x}}$ controls under IMO legislation will help level emissions growth into the 2020-2030 decade but will be outstripped by growth in shipping activity. If MFR controls for fine particles such as BC are implemented, the technologies are expected to capture all PM with similar efficacy; this leads to expected reductions in OC with MFR policies.

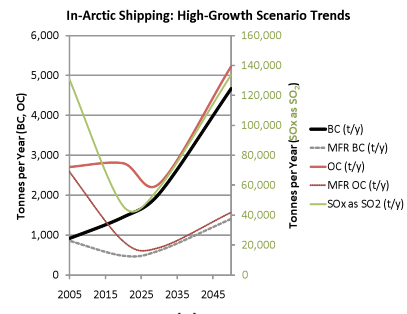

(a)

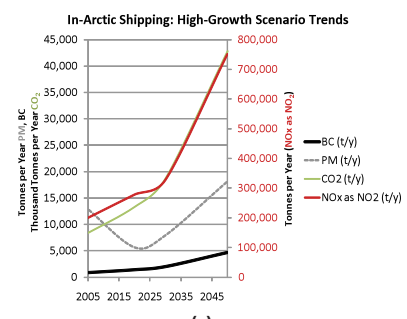

(c)

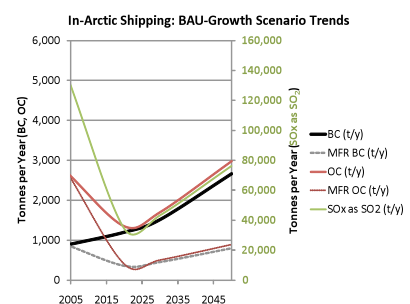

(b)

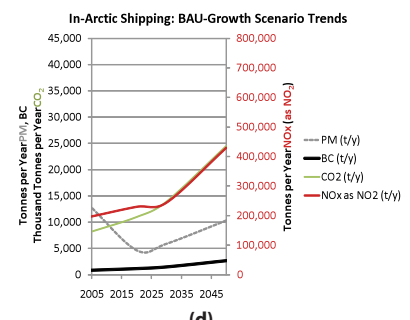

(d)
Fig. 3. Comparison of in-Arctic trends for black carbon, organic carbon, and $\mathrm{SO}_{\mathrm{x}}$ emissions under (a) high growth and (b) BAU scenarios. Also shown are the comparison of black carbon, particulate matter, $\mathrm{CO}_{2}$ and $\mathrm{NO}_{\mathrm{x}}$ under (c) high growth and (d) BAU scenarios.

Black carbon emissions from shipping in the Arctic can be evaluated in terms of in-Arctic ship activity, with and without potential diversion of global shipping to navigable Arctic routes for diversion traffic, and with regard to global (nonArctic) shipping inventories. Table 13 presents these results for high-growth scenarios with and without control action to achieve maximum feasible reductions; Table 14 presents these results for the BAU scenario. Based on evaluation of emissions alone, in-Arctic shipping contributes modestly to total BC from shipping; in 2004, Arctic transport vessels contributed less than $1 \%$ of ship BC emissions, and in 2050 ships may contribute less than $2.5 \%$ of global ship BC emissions.

Effects of the inclusion of navigable routes for diversion traffic in the Arctic are illustrated for BC in Fig. 4. In 2030, diversion traffic (if ice-free) at only $2 \%$ of global shipping (about half of the Panama Canal volume currently and much less than the Suez Canal volume) the diversion traffic could rival emissions from future in-Arctic traffic. By 2050, diversion traffic could dominate shipping sources of Arctic emissions. MFR scenarios can substantially reduce shipping pollution in the Arctic, but growth and diversion may still produce higher emissions of $\mathrm{BC}$ and other pollutants in later decades (Fig. 4b).

Regulatory action could be merited if the mitigating benefits are substantial, given that low-sulfur marine fuels will enable technological feasibility to control ship BC and other PM species. While modeling studies need to be conducted to demonstrate and quantify the potential benefits, our MFR scenario shows that with controls Arctic BC from shipping can be reduced in the near-term and held nearly constant through 2050. The MFR scenario affords greater opportunity 
Table 8. Summary of in-Arctic emissions inventories for 2004 and BAU projections.

\begin{tabular}{lllll}
\hline BAU Scenarios & 2004 & 2020 & 2030 & 2050 \\
\hline $\mathrm{CO}_{2}(\mathrm{mt} / \mathrm{y})$ & 8100000 & 11000000 & 14000000 & 24000000 \\
$\mathrm{NO}_{\mathrm{x}}$ as $\mathrm{NO}_{2}(\mathrm{mt} / \mathrm{y})$ & 196000 & 231000 & 244000 & 429000 \\
$\mathrm{SO}_{\mathrm{x}}$ as $\mathrm{SO}_{2}(\mathrm{mt} / \mathrm{y})$ & 136000 & 34000 & 43000 & 76000 \\
$\mathrm{PM}(\mathrm{mt} / \mathrm{y})$ & 13000 & 4700 & 5900 & 10000 \\
$\mathrm{CO}(\mathrm{mt} / \mathrm{y})$ & 19000 & 25000 & 32000 & 56000 \\
$\mathrm{BC}(\mathrm{mt} / \mathrm{y})$ & 880 & 1200 & 1500 & 2700 \\
$\mathrm{OC}(\mathrm{mt} / \mathrm{y})$ & 2700 & 1300 & 1700 & 3000 \\
$\mathrm{MFR} \mathrm{BC}(\mathrm{mt} / \mathrm{y})$ & 880 & 360 & 460 & 800 \\
$\mathrm{MFR} \mathrm{OC}(\mathrm{mt} / \mathrm{y})$ & 2700 & 400 & 510 & 890 \\
\hline
\end{tabular}

${ }^{1} \mathrm{PM}$ reductions result from current legislation to reduce $\mathrm{SO}_{\mathrm{x}}$ emissions from ships through marine fuel standards and associated decreases in $\mathrm{OC}$ due to lower-sufur fuels (Buhaug et al., 2009; Lack et al., 2008, 2009). MFR scenarios aimed at BC would reduce total PM as well, by controlling BC directly and indirectly by reducing OC emissions.

Table 9. Summary of in-Arctic emission inventories for 2004 and high-growth projections.

\begin{tabular}{lllll}
\hline High Growth Scenarios & 2004 & 2020 & 2030 & 2050 \\
\hline $\mathrm{CO}_{2}(\mathrm{mt} / \mathrm{y})$ & 8100000 & 13000000 & 19000000 & 43000000 \\
$\mathrm{NO}_{\mathrm{x}}$ as $\mathrm{NO}_{2}(\mathrm{mt} / \mathrm{y})$ & 196000 & 279000 & 329000 & 752000 \\
$\mathrm{SO}_{\mathrm{x}}$ as SO \\
$\mathrm{PM}(\mathrm{mt} / \mathrm{m})$ & 136000 & 46000 & 58000 & 133000 \\
$\mathrm{CO}(\mathrm{mt} / \mathrm{y})$ & 13000 & 5600 & 7900 & 18000 \\
$\mathrm{BC}(\mathrm{mt} / \mathrm{y})$ & 19000 & 31000 & 43000 & 99000 \\
$\mathrm{OC}(\mathrm{mt} / \mathrm{y})$ & 880 & 1500 & 2000 & 4700 \\
$\mathrm{MFR} \mathrm{BC}(\mathrm{mt} / \mathrm{y})$ & 2700 & 2800 & 2300 & 5200 \\
$\mathrm{MFR} \mathrm{OC}(\mathrm{mt} / \mathrm{y})$ & 880 & 480 & 610 & 1400 \\
\hline
\end{tabular}

${ }^{1} \mathrm{PM}$ reductions result from current legislation to reduce $\mathrm{SO}_{\mathrm{x}}$ emissions from ships through marine fuel standards and associated decreases in OC due to lower-sufur fuels (Buhaug et al., 2009; Lack et al., 2008, 2009). MFR scenarios aimed at BC would reduce total PM as well, by controlling BC directly and indirectly by reducing OC emissions.

to compare and explore the merits of policy action on shortlived forcing pollutants from ships.

\subsection{Framing potential impacts}

Given that shorter routes will be associated with avoided $\mathrm{CO}_{2}$ emissions compared to longer routes, assessing the shortlived climate forcing components of these scenarios is important.

Potential exists for direct radiative forcing (cooling and warming) in the Arctic by vessel-emitted PM. This has yet to be evaluated and will depend on specifics of PM albedo, surface albedo and absolute emissions, now provided specifically for the Arctic. Indirect radiative forcing (cooling and warming) can also result from vessel-emitted PM. As described by Mauritsen et al. (2010), indirect warming in the Arctic can result from injection of cloud condensation nuclei $(\mathrm{CCN})$ in a $\mathrm{CCN}$ limited environment $\left(<10 \mathrm{CCN} \mathrm{cm}^{-3}\right)$. PM from commercial shipping burning high sulfur fuel will contribute to CCN (Lack et al., 2009) and may contribute to warming if emitted within the Arctic. The inventories developed here provide PM distributions which can be used to determine Arctic shipping CCN distributions (Lack et al., 2009; Petzold et al., 2010). By also developing Arctic ship emission inventories for maximum feasible reductions and following international policy on fuel sulfur content, the impacts of future regulation on the changes to $\mathrm{CCN}$ and the subsequent warming impact can also be assessed.

A first-order comparator can assess the relative potential of non- $\mathrm{CO}_{2}$ species to contribute to global warming potential (GWP) and to global temperature change potential (GTP). Simplified expressions of these terms, combining both direct and indirect effect estimates, have been derived by $\mathrm{Fu}$ glestvedt et al. (2010) for transportation sources of shortlived pollutants. These metrics have informed climate policy implementation decisions by assessing, in a common metric, the net climate impact of technological, policy or operational changes of a mode of transport. Global warming potential is based on the time-integrated radiative forcing due to a pulse emission of a unit mass of gas, and can be calculated for various time intervals. Global temperature change potential provides a metric for the response of the global-mean surface temperature, representing potential temperature change at a given time due to a pulse emission (Shine et al., 2005). 
Table 10. Summary of potential emission inventories from diverted global shipping to Arctic routes.

\begin{tabular}{llllllll}
\hline Diversions Summary & $\mathrm{CO}_{2}(\mathrm{mt} / \mathrm{y})$ & $\mathrm{NO}_{\mathrm{x}}(\mathrm{mt} / \mathrm{y})$ & $\mathrm{SO}_{\mathrm{x}}(\mathrm{mt} / \mathrm{y})$ & $\mathrm{PM}(\mathrm{mt} / \mathrm{y})$ & $\mathrm{CO}(\mathrm{mt} / \mathrm{y})$ & $\mathrm{BC}(\mathrm{mt} / \mathrm{y})$ & $\mathrm{OC}(\mathrm{mt} / \mathrm{y})$ \\
\hline 2020 High-Growth & 8400000 & 180000 & 26000 & 3500 & 19000 & 910 & 1000 \\
2030 High-Growth & 23100000 & 410000 & 72000 & 10000 & 53000 & 2500 & 2800 \\
2050 High-Growth & 110400000 & 1900000 & 344000 & 47000 & 255000 & 12000 & 13500 \\
2020 BAU & 6400000 & 130000 & 20000 & 2700 & 15000 & 700 & 800 \\
2030 BAU & 7900000 & 140000 & 25000 & 3400 & 18000 & 900 & 1000 \\
2050 BAU & 21700000 & 380000 & 68000 & 9200 & 50000 & 2400 & 2700 \\
\hline
\end{tabular}

High-growth diversions in 2020, 2030, and 2050 are 1\%, 2\%, and 5\% of global shipping in each of those future years, respectively. Global shipping growth outside of Arctic is $\sim 3.3 \%$ per year.

BAU diversions in 2020, 2030, and 2050 are $1 \%, 1 \%$, and $1.8 \%$ of global shipping in each of those future years, respectively. Global shipping growth outside of Arctic is $~ 2.1 \%$ per year.

Table 11. Flexibility in diversion route allocation scenarios.

\begin{tabular}{lllll}
\hline Route allocation ratios & Equally & Non-polar & Polar-only & Singly \\
\hline Northeast Passage (NEP in Red) & $25 \%$ & $50 \%$ & $0 \%$ & $100 \%$ \\
Northwest Passage (NWP in Light Blue) & $25 \%$ & $50 \%$ & $0 \%$ & $100 \%$ \\
Western Polar Route (WPR in Dark Blue) & $25 \%$ & $0 \%$ & $50 \%$ & $100 \%$ \\
Eastern Polar Route (EPR in Orange) & $25 \%$ & $0 \%$ & $50 \%$ & $100 \%$ \\
\hline
\end{tabular}

Note: Allocations above provided in data for this work; other allocations possible. Colors correspond to Fig. 1f.

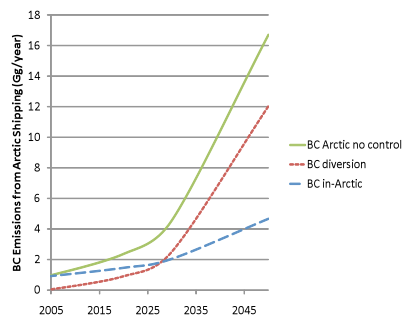

(a)

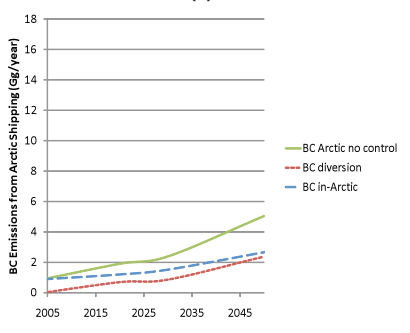

(c)
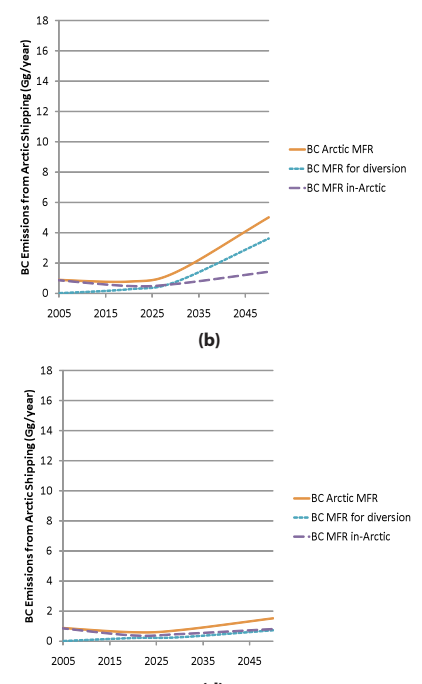

(d)

Fig. 4. Comparison of in-Arctic and potential diversion trends for black carbon through 2050 with the following scenarios: (a) high growth - no control, (b) and high growth - MFR control, (c) BAU - no control and (d) BAU - MFR control.

While GWP and GTP ratios are subject to substantial debate and uncertainty (Boucher et al, 2008; Reisinger et al, 2010), comparisons have been made in other contexts to help inform the merits of policy decisions regarding feasible reductions (Kristin et al, 2009). Default relationships are

available using radiative forcings and lifetimes from the literature to derive GWPs and GTPs for the main transportrelated emissions, although more work will be needed to calibrate these to Arctic conditions and reduce uncertainties. Using Fuglestvedt et al. (2009) default parameters on a 20-year horizon, we estimate first-order comparisons of non- $\mathrm{CO}_{2}$ emissions from in-Arctic shipping activity in 2030 (Table 15).

The GWP contribution in 2030 of uncontrolled BC from Arctic shipping is in the range of $17 \%$ to $78 \%$ of $\mathrm{CO}_{2}$ GWP from ships under the high-growth scenario; GTP contribution is about $5 \%$ or more of $\mathrm{CO}_{2}$ from ships. These ranges are perhaps lower-bound estimates, given the exclusion in this estimate of fishing vessels and dissimilar impact potential for near-ice emissions. Higher-range estimates here use the GWP from Jacobson (2010) who suggested that the 20-year GWP for BC from fossil fuel soot is a factor of 3-5 greater than Fuglesvedt et al. (2009). In addition to the direct and indirect forcing effects, these inventories can be used to update estimates of tropospheric ozone forcing from Arctic shipping (Granier et al., 2006), and to assess additional albedo effects on snow and ice (Hegg et al., 2010). We recognize that Arctic shipping's contribution to climate change remains highly uncertain for all particulate emissions and for $\mathrm{NO}_{\mathrm{x}}$.

These scientific uncertainties are joined by possible changes described by the future scenarios provide here. As reported in Table 15, the MFR scenarios reduce BC and OC forcing by a factor of three, illustrating the relative benefit 
Table 12. Example of future through-Arctic shipping traffic diversions.

\begin{tabular}{lllllll}
\hline Year & Global Shipping Diverted & Diversion Months & NEP & NWP & EPR & WPR \\
\hline $2010-2020$ & $1 \%$ & Aug, Sep, Oct & $100 \%$ & $0 \%$ & $0 \%$ & $0 \%$ \\
$2020-2030$ & $2 \%$ & Aug, Sep, Oct & $50 \%$ & $50 \%$ & $0 \%$ & $0 \%$ \\
$2031-2040$ & $3.5 \%$ & Jul, Aug, Sep, Oct & $40 \%$ & $40 \%$ & $10 \%$ & $10 \%$ \\
$2041-2050$ & $5 \%$ & Jul, Aug, Sep, Oct, Nov & $25 \%$ & $25 \%$ & $25 \%$ & $25 \%$ \\
\hline
\end{tabular}

Table 13. High-growth scenarios for black carbon, with and without emissions control.

\begin{tabular}{|c|c|c|c|c|c|}
\hline Units: $\mathrm{Gg} / \mathrm{yr}$ & $2001^{1}$ & $2004^{2}$ & 2020 & 2030 & 2050 \\
\hline $\mathrm{BC}$ non-Arctic & $\begin{array}{l}130 \\
(100 \%)^{3}\end{array}$ & $\begin{array}{l}140 \\
(99.39 \%)\end{array}$ & $\begin{array}{l}270 \\
(99.14 \%)\end{array}$ & $\begin{array}{l}380 \\
(98.80 \%)\end{array}$ & $\begin{array}{l}710 \\
(97.70 \%)\end{array}$ \\
\hline \multicolumn{6}{|c|}{ No Controls, High-Growth Scenario } \\
\hline BC in-Arctic & & $\begin{array}{l}0.9 \\
(0.61 \%)\end{array}$ & $\begin{array}{l}1.5 \\
(0.53 \%)\end{array}$ & $\begin{array}{l}2.0 \\
(0.54 \%)\end{array}$ & $\begin{array}{l}4.7 \\
(0.64 \%)\end{array}$ \\
\hline $\mathrm{BC}$ diversion traffic & & $\begin{array}{l}0 \\
(0.00 \%)\end{array}$ & $\begin{array}{l}0.9 \\
(0.33 \%)\end{array}$ & $\begin{array}{l}2.5 \\
(0.66 \%)\end{array}$ & $\begin{array}{l}12.0 \\
(1.66 \%)\end{array}$ \\
\hline BC Arctic no control & & $\begin{array}{l}0.9 \\
(0.61 \%)\end{array}$ & $\begin{array}{l}2.4 \\
(0.86 \%)\end{array}$ & $\begin{array}{l}4.6 \\
(1.20 \%)\end{array}$ & $\begin{array}{l}17.0 \\
(2.30 \%)\end{array}$ \\
\hline BC Global with Arctic & 130 & 142 & 275 & 389 & 744 \\
\hline \multicolumn{6}{|c|}{ Maximum Feasible Regulatory (MFR) Controls, High-Growth Scenario } \\
\hline BC MFR in-Arctic & & $\begin{array}{l}0.9 \\
(0.61 \%)\end{array}$ & $\begin{array}{l}0.4 \\
(0.18 \%)\end{array}$ & $\begin{array}{l}0.6 \\
(0.16 \%)\end{array}$ & $\begin{array}{l}1.4 \\
(0.20 \%)\end{array}$ \\
\hline BC MFR for diversion & & $\begin{array}{l}0.0 \\
(0.00 \%)\end{array}$ & $\begin{array}{l}0.3 \\
(0.10 \%)\end{array}$ & $\begin{array}{l}0.8 \\
(0.20 \%)\end{array}$ & $\begin{array}{l}3.6 \\
(0.50 \%)\end{array}$ \\
\hline BC Arctic MFR & & $\begin{array}{l}0.9 \\
(0.61 \%)\end{array}$ & $\begin{array}{l}0.8 \\
(0.28 \%)\end{array}$ & $\begin{array}{l}1.4 \\
(0.36 \%)\end{array}$ & $\begin{array}{l}5.0 \\
(0.70 \%)\end{array}$ \\
\hline BC Global with Arctic MFR & 130 & 142 & 272 & 383 & 720 \\
\hline
\end{tabular}

\footnotetext{
1 Note: Values rounded for presentation to two significant figures;

Previous estimate per Lack et al. (2008; 2009);

${ }^{2}$ Updated estimate given in-Arctic data (this work);

3 Percentages represent percent of global BC, presuming that in-Arctic emissions reported here are additive to previous global inventories and allowing for diversion according to scenarios reported here.
}

of controlling short-lived forcing pollutants. Moreover, these results may be different if diversion routes through the Arctic do not capture $\sim 2 \%$ of global traffic in 2030 as our scenario suggests, either due to non-navigable routes or vessel traffic restrictions; some 55\% of GWP and GTP estimated for 2030 are due to diversion scenario shipping. Notably, sulfate produces negative forcing equivalent to about $25 \%$ and $7 \%$ of GWP and GTP, respectively, in 2030. Using the 2030 time period for this example reveals the potential for projected growth in shipping to offset the environmental benefits of current legislation reducing marine fuel sulfur content by 2020 (International Maritime Organization, 2008).

Modeling potential impacts using these inventories will clarify both the assessment of impacts and mitigation potential attributable to Arctic shipping. Arctic-specific metrics will improve the first-order assessment for shipping, as has been done for other sources (Quinn et al., 2008). In order to inform technological and policy decisions, important comparisons that are needed include (a) the relative contribution to the climate impact of short-lived pollutants in the Arctic by in-Arctic shipping, non-Arctic shipping, and other anthropogenic sources; (b) mitigation provided by MFR scenarios for Arctic shipping relative to other strategies to control short-lived forcing pollutants from other sources; (c) cost-benefit and cost-effectiveness of action to control shipping emissions impacting Arctic conditions, and (d) ranking in-Arctic controls and non-Arctic controls alongside nonshipping costs and benefits. Beyond this, the data sources can be modified to produce new vessel-specific Arctic shipping scenarios as Arctic climate policy strategies and targets are clarified. Inventory data are posted at (http://coast.cms. udel.edu/ArcticShipping/). 
Table 14. BAU-growth scenarios for black carbon, with and without emissions control.

\begin{tabular}{|c|c|c|c|c|c|}
\hline Units: $\mathrm{Gg} / \mathrm{yr}$ & $2001^{1}$ & $2004^{2}$ & 2020 & 2030 & 2050 \\
\hline $\mathrm{BC}$ non-Arctic & $\begin{array}{l}130 \\
(100 \%)^{3}\end{array}$ & $\begin{array}{l}140 \\
(99.39 \%)\end{array}$ & $\begin{array}{l}210 \\
(99.10 \%)\end{array}$ & $\begin{array}{l}260 \\
(99.09 \%)\end{array}$ & $\begin{array}{l}393 \\
(98.73 \%)\end{array}$ \\
\hline \multicolumn{6}{|c|}{ No Controls, High-Growth Scenario } \\
\hline $\mathrm{BC}$ in-Arctic & & $\begin{array}{l}0.9 \\
(0.61 \%)\end{array}$ & $\begin{array}{l}1.2 \\
(0.57 \%)\end{array}$ & $\begin{array}{l}1.5 \\
(0.58 \%)\end{array}$ & $\begin{array}{l}2.7 \\
(0.67 \%)\end{array}$ \\
\hline $\mathrm{BC}$ diversion & & $\begin{array}{l}0.0 \\
(0.00 \%)\end{array}$ & $\begin{array}{l}0.7 \\
(0.33 \%)\end{array}$ & $\begin{array}{l}0.9 \\
(0.33 \%)\end{array}$ & $\begin{array}{l}2.4 \\
(0.60 \%)\end{array}$ \\
\hline BC Arctic no control & & $\begin{array}{l}0.9 \\
(0.63 \%)\end{array}$ & $\begin{array}{l}1.9 \\
(0.90 \%)\end{array}$ & $\begin{array}{l}2.4 \\
(0.91 \%)\end{array}$ & $\begin{array}{l}5.0 \\
(1.27 \%)\end{array}$ \\
\hline BC Global with Arctic & 130 & 142 & 214 & 265 & 403 \\
\hline \multicolumn{6}{|c|}{ Maximum Feasible Regulatory (MFR) Controls, High-Growth Scenario } \\
\hline BC MFR in-Arctic & & $\begin{array}{l}0.9 \\
(0.63 \%)\end{array}$ & $\begin{array}{l}0.4 \\
(0.17 \%)\end{array}$ & $\begin{array}{l}0.5 \\
(0.18 \%)\end{array}$ & $\begin{array}{l}0.8 \\
(0.20 \%)\end{array}$ \\
\hline BC MFR for diversion & & $\begin{array}{l}0 \\
(0.00 \%)\end{array}$ & $\begin{array}{l}0.20 \\
(0.10 \%)\end{array}$ & $\begin{array}{l}0.3 \\
(0.10 \%)\end{array}$ & $\begin{array}{l}0.7 \\
(0.18 \%)\end{array}$ \\
\hline BC Arctic MFR & & $\begin{array}{l}0.9 \\
(0.63 \%)\end{array}$ & $\begin{array}{l}0.8 \\
(0.27 \%)\end{array}$ & $\begin{array}{l}1.4 \\
(0.28 \%)\end{array}$ & $\begin{array}{l}5.0 \\
(0.38 \%)\end{array}$ \\
\hline BC Global with Arctic MFR & 130 & 142 & 211 & 262 & 400 \\
\hline
\end{tabular}

\footnotetext{
${ }^{1}$ Note: Values rounded for presentation to two significant figures.

Previous estimate per Lack et al. (2008, 2009);

2 Updated estimate given in-Arctic data (this work);

3 Percentages represent percent of global BC, presuming that in-Arctic emissions reported here are additive to previous global inventories and allowing for diversion according to scenarios reported here.
}

Table 15. Estimated 20-year GWP and GTP for 2030 projections of Arctic shipping and potential diversions (Fuglestvedt et al., 2010).

\begin{tabular}{|c|c|c|c|c|c|c|}
\hline Pollutant & $\begin{array}{l}\text { Diversion } \\
(\mathrm{Gg} / \mathrm{y})\end{array}$ & $\begin{array}{l}\text { In-Arctic } \\
(\mathrm{Gg} / \mathrm{y})\end{array}$ & $\begin{array}{l}\text { GWP Ratio } \\
\text { to } \mathrm{CO}_{2}\end{array}$ & $\begin{array}{l}\mathrm{Gg} \mathrm{CO}_{2} \text { eq } \\
\mathrm{GWP}\end{array}$ & $\begin{array}{l}\text { GTP Ratio to } \\
\mathrm{CO}_{2}\end{array}$ & $\begin{array}{l}\mathrm{Gg} \mathrm{CO}_{2} \text { eq } \\
\text { GTP }\end{array}$ \\
\hline Carbon Dioxide & 23100 & 18700 & 1 & 41800 & 1 & 41800 \\
\hline $\begin{array}{l}\text { Black Carbon (BC) } \\
\text { (using Jacobson, 2010) }\end{array}$ & 2.5 & 2.0 & $\begin{array}{l}1600 \\
4500-7200\end{array}$ & $\begin{array}{l}7235 \\
20300-32400\end{array}$ & 470 & 2125 \\
\hline MFR BC & 0.8 & 0.6 & & 2171 & & 638 \\
\hline Organic Carbon (OC) & 2.8 & 2.3 & -240 & (1229) & -71 & (364) \\
\hline MFR OC & 0.8 & 0.7 & & $(369)$ & & (109) \\
\hline Carbon Monoxide & 53.0 & 43.0 & 7 & 674 & 4.6 & 443 \\
\hline Sulfate $^{1}$ & 28.0 & 45.0 & -140 & (10 268) & -41 & (3007) \\
\hline
\end{tabular}

${ }^{1}$ Assumes that $\mathrm{SO}_{\mathrm{x}}$ emitted by ships converts to sulfate with $26 \%$ conversion ratio, per Khoder (2002); modeled results would be required to verify or update this.

\section{Conclusions}

Shipping activity patterns are dynamic but predictable, and exhibit substantial seasonality in the Arctic region. Estimates of emissions from shipping can be less uncertain than other sources but more variable in terms of engine technologies, fuel quality, and installed power; shipping emissions are also mobile, which makes their location variable even when obtained through direct reporting activities. In this work, uncertainties in base estimates are similar to uncertainties in other shipping inventories at large-regional scales. Moreover, the ability of marine diesel engines to produce very large numbers of small BC particles may result in disproportionate impact on ice, snow, and cloud albedo. More uncertainties are associated with trend scenarios, so we produced both high growth and BAU trends. The construction of these trends matches independently produced inventories by other researchers, which suggests that this work introduces no new systemic biases from other work and that the high-resolution distribution of ship emissions may be useful 
to current assessment efforts. More generally, we acknowledge that the magnitude of emissions from shipping on a mass basis may be modest compared to other anthropogenic sources, but the proximity of activity to the Arctic may help explain regional effects important for global and regional climate change. With this work, scientific inquiry can assess whether effects from shipping are important and evaluate the potential for control activities to provide mitigation or other benefits.

Acknowledgements. This work was made possible by the assistance and support of a number of groups and individuals. The work of the Arctic Council in producing the Arctic Marine Shipping Assessment, and the efforts of lead and contributing authors to that study resulted in the underlying data for this work. Partial sponsors include the Clean Air Task Force, Transport Canada, Energy and Environmental Research Associates, ClimateWorks, the International Council on Clean Transportation, and NOAA's Climate Program. Erin Green provided important insights into determining MFR scenario control efficacy. Any opinions expressed in this paper are those of the authors and do not constitute official positions or policy of sponsoring or affiliated organizations.

Edited by: N. Riemer

\section{References}

ACIA: Impacts of a Warming Arctic: Arctic Climate Impact Assessment, Cambridge University Press, 140 pp., 2004.

Arctic Council: available online at: http://arctic-council.org/ filearchive/TromsoeDeclaration-1..pdf: last access: 12 October 2010, 2009a.

Arctic Council, Coordinating Lead Authors: Brigham, L., McCalla, R., Cunningham, E., Barr, W., Vanderzaag, D., Santos-Pedro, V., MacDonald, R., Harder, S., et al.: Arctic Marine Shipping Assessment 2009 Report, edited by: Ellis, B., and Brigham, L., Arctic Council, Tromsa, Norway, 194 pp., 2009 b.

Bond, T. C., Streets, D. G., Yarber, K. F., Nelson, S. M., Woo, J.H., and Klimont, Z.: A technology-based global inventory of black and organic carbon emissions from combustion, J. Geophys. Res., 109, D14203, doi: 10.1029/2003JD003697, 2004.

Boucher, O. and Reddy, M. S.: Climate trade-off between black carbon and carbon dioxide emissions, Energy Policy, 36(1), 193200, 2008.

Buhaug, Ø., Corbett, J. J., Endresen, Ø., Eyring, V., Faber, J., Hanayama, S., Lee, D. S., Lee, D., Lindstad, H., Mjelde, A., et al.: Second IMO Greenhouse Gas Study 2009, International Maritime Organization, London, 2009.

Caiazzo, G., Nardo, A. D., Langella, G., and Noviello, C.: Numerical evaluation of seawater scrubbers efficiency for exhaust gas desulphurization, Combustion Colloquia, 32nd Meeting on Combustion: Italian Section of the Combustion Institute, Napoli, Italy, 2009,

Capaldo, K. P., Corbett, J. J., Kasibhatla, P., Fischbeck, P., and Pandis, S. N.: Effects of Ship Emissions on Sulphur Cycling and Radiative Climate Forcing Over the Ocean, Nature, 400, 743-746, 1999.
Corbett, J. J. and Koehler, H. W.: Updated Emissions from Ocean Shipping. J. Geophys. Res.-Atmos., 108(D20), 46504666, 2003.

Corbett, J. J., Wang, C., Winebrake, J. J., and Green, E.: Review of Marpol Annex VI and the $\mathrm{NO}_{\mathrm{x}}$ Technical Code: Allocation and Forecasting of Global Ship Emissions, International Maritime Organization, London, UK, 27 pp., 2007.

Cooper, D. A.: Methodology for calculating emissions from ships: 1. Update of emission factors; IVL: 2 February, 2004.

Dalsoren, S. B., Endresen, O., Isaksen, I. S. A., Gravir, G., and Sorgard, E.: Environmental impacts of the expected increase in sea transportation, with a particular focus on oil and gas scenarios for Norway and northwest Russia, J. Geophys. Res., 112, D02310, doi:10.1029/2005JD006927, 2007.

Suez Canal Statistics: available online at: http://www.emdb.gov. eg/english/inside_e.aspx?main=suezcanal\&level $1=$ totals, access: 19 January 2010, 2010.

Entec UK Limited, Ritchie, A., Jonge, E. d., Hugi, C., and Cooper, D.: European Commission Directorate General Environment, Service Contract on Ship Emissions: Assignment, Abatement, and Market-based Instruments. Task 2c - SO2 Abatement, Entec UK Limited, Northwich, Cheshire, UK, 2005.

Eyring, V., Isaksen, I. S. A., Berntsen, T., Collins, W. J., Corbett, J. J., Endresen, O., Grainger, R. G., Moldanova, J., Schlager, H., and Stevenson, D. S.: Assessment of Transport Impacts on Climate and Ozone: Shipping, Atmos. Environ., 44(37), 47354771, doi:10.1016/j.atmosenv.2009.04.059, 2010.

Flanner, M. G., Zender, C. S., Randerson, J. T., and Rasch, P. $\mathrm{J}$.: Present-day climate forcing and response from black carbon in snow, Journal of Geophysical Research-Atmospheres, 112, D11202, doi:10.1029/2006jd008003, 2007.

Flanner, M. G., Zender, C. S., Hess, P. G., Mahowald, N. M., Painter, T. H., Ramanathan, V., and Rasch, P. J.: Springtime warming and reduced snow cover from carbonaceous particles, Atmos. Chem. Phys., 9, 2481-2497, doi:10.5194/acp-9-24812009, 2009.

Fuglestvedt, J., Berntsen, T., Myhre, G., Rypdal, K., and Skeie, R. B.: Climate forcing from the transport sectors, Proc. Natl. Acad. Sci., 105, 454-458, doi:10.1073/pnas.0702958104, 2008.

Fuglestvedt, J., Berntsen, T., Eyring, V., Isaksen, I., Lee, D. S., and Sausen, R.: Shipping Emissions: From Cooling to Warming of Climate and Reducing Impacts on Health, Environ. Sci. Technol., 43, 9057-9062, 2009.

Fuglestvedt, J. S., Shine, K. P., Berntsen, T., Cook, J., Lee, D. S., Stenke, A., Skeie, R. B., Velders, G. J. M., and Waitz, I. A.: Transport impacts on atmosphere and climate: Metrics, Atmospheric Environment, corrected proof, 44(36), 4648-4677, doi:10.1016/j.atmosenv.2009.04.044, 2010.

Globalsecurity.org, Panama Canal Operations: available online at: http://www.globalsecurity.org/military/facility/ panama-canal-ops.htm, last access: 19 January 2010, 2010.

Granier, C., Niemeier, U., Jungclaus, J. H., Emmons, L., Hess, P., Lamarque, J.-F., Walters, S., and Brasseur, G. P.: Ozone pollution from future ship traffic in the Arctic northern passages, Geophys. Res. Lett., 33(5), L13807, doi:10.1029/2006GL026180, 2006.

Hansen, J. and Nazarenko, L.: Soot climate forcing via snow and ice albedos, Proceedings of the National Academy of Sciences of the United States of America, 101, 423-428, 
doi:10.1073/pnas.2237157100, 2004.

Hansen, J., Sato, M., Ruedy, R., Nazarenko, L., Lacis, A., Schmidt, G. A., Russell, G., Aleinov, I., Bauer, M., Bauer, S., et al.: Efficacy of climate forcings, J. Geophys. Res.-Atmos., 110, D18104, 10.1029/2005jd005776, 2005.

IPCC: Climate Change 2007: Synthesis Report; Contribution of Working Groups I, II and III to the Fourth Assessment Report of the Intergovernmental Panel on Climate Change, Geneva, Switzerland, 104, ISBN 92-9169-122-4, 2007.

Jakobson, L.: China Prepares for an Ice-Free Arctic, SIPRI Insights on Peace and Security, 2, D14209, doi:10.1029/2009JD013795, 2010.

Jacobson, M. Z.: Short-term effects of controlling fossil-fuel soot, biofuel soot and gases, and methane on climate, Arctic ice, and air pollution health, J. Geophys. Res., 115(D14), D14209, doi:10.1029/2009JD013795, 2010.

Khoder, M. I.: Atmospheric conversion of sulfur dioxide to particulate sulfate and nitrogen dioxide to particulate nitrate and gaseous nitric acid in an urban area, Chemosphere, 49, 675-684, 2002.

Kristin, R., Nathan, R., Terje K. B., Zbigniew, K., Torben K. M., Gunnar, M., and Ragnhild, B. S.: Costs and global impacts of black carbon abatement strategies, Tellus B, 61(4), 625-641, 2009.

Hegg, D. A., Warren, S. G., Grenfell, T. C., Doherty, S. J., and Clarke, A. D.: Sources of light-absorbing aerosol in arctic snow and their seasonal variation, Atmos. Chem. Phys. Discuss., 10, 13755-13796, doi:10.5194/acpd-10-13755-2010, 2010.

Holland America Line Sea Water Scrubber Demonstration Project: http://www.fasterfreightcleanerair.com/pdfs/Presentations/ FFCAPNW2008/DaveKircherpresentationFFCAPNW.pdf, last access: 15 January, 2008.

Lack, D., Lemer, B., Granier, C., Baynard, T., Lovejoy, E., Massoli, P., Ravishankara, A. R., and Williams, E.: Light absorbing carbon emissions from commercial shipping, Geophys. Res. Lett., 35, L13815, doi:10.1029/2008GL03390, 2008.

Lack, D. A., Corbett, J. J., Onasch, T., Lerner, B., Massoli, P., Quinn, P. K., Bates, T. S., Covert, D. S., Coffman, D., Sierau, B., et al.: Particulate emissions from commercial shipping: Chemical, physical, and optical properties, J. Geophys. Res., 114, D00F04, doi:10.1029/2008JD011300, 2009.

Lauer, A., Eyring, V., Corbett, J. J., Wang, C., and Winebrake, J. J.: An assessment of near future policy instruments for international shipping: Impact on atmospheric aerosol burdens and the Earth's radiation budget, Environ. Sci. Technol., 43(15), 55925598, doi:10.1021/es900922h, 2009.

Lyyranen, J., Jokiniemi, J., Kauppinen, E. I., and Joutsensaari, J.: Aerosol Characterisation In Medium-Speed Diesel Engines Operating With Heavy Fuel Oils, J. Aerosol Sci., 30, 771-784, 1999.

Mauritsen, T., Sedlar, J., Tjernstrm, M., Leck, C., Martin, M., Shupe, M., Sjogren, S., Sierau, B., Persson, P. O. G., Brooks, I. M., and Swietlicki, E.: Aerosols indirectly warm the Arctic, Atmos. Chem. Phys. Discuss., 10, 16775-16796, doi:10.5194/acpd-10-16775-2010, 2010.

Mjelde, A. and Hustad, H.: Teknisk Rapport: Driftsutslipp til luft og sjø fra skipstrafikk i norske havområder, Det Norske Veritas, Rapport Nr.: 2007-2030, rev. 02, 28 pp., 2009.

Moldanová, J., Fridell, E., Popovicheva, O., Demirdjian, B., Tishkova, V., Faccinetto, A., and Focsa, C.: Characterisation of particulate matter and gaseous emissions from a large ship diesel engine, Atmos. Environ., 43, 2632-2641, 2009.

Arctic Sea Ice Shatters All Previous Record Lows. Diminished summer sea ice leads to opening of the fabled Northwest Passage, available online at: http://nsidc.org/news/press/2007_ seaiceminimum/20071001_pressrelease.html, 2007.

Paxian, A., Eyring, V., Beer, W., Sausen, R., and Wright, C.: Present-Day and Future Global Bottom-Up Ship Emission Inventories Including Polar Routes, Environ. Sci. Technol., 44(4), 1333-1339, doi:10.1021/ES9022859, 2010.

Petzold, A., Hasselbach, J., Lauer, P., Baumann, R., Franke, K., Gurk, C., Schlager, H., and Weingartner, E.: Experimental studies on particle emissions from cruising ship, their characteristic properties, transformation and atmospheric lifetime in the marine boundary layer, Atmos. Chem. Phys., 8, 2387-2403, 2008, http://www.atmos-chem-phys.net/8/2387/2008/.

Petzold, A., Weingartner, E., Hasselbach, J., Lauer, P., Kurok, C., and Fleischer, F.: Physical Properties, Chemical Composition, and Cloud Forming Potential of Particulate Emissions from a Marine Diesel Engine at Various Load Conditions, Environ. Sci. Technol., 44(10), 3800-3805, 2010.

Plain sailing on the Northwest Passage, available online at: http: //news.bbc.co.uk/2/hi/americas/6999078.stm, 2007.

Quinn, P. K., Bates, T. S., Baum, E., Doubleday, N., Fiore, A. M., Flanner, M., Fridlind, A., Garrett, T. J., Koch, D., Menon, S., et al.: Short-lived pollutants in the Arctic: their climate impact and possible mitigation strategies, Atmos. Chem. Phys., 8, 17231735, 2008, http://www.atmos-chem-phys.net/8/1723/2008/.

Ramanathan, V. and Carmichael, G.: Global and regional climate changes due to black carbon, Nat. Geosci., 1, 221-227, 2008.

Reddy, S. M. and Boucher, O.: Climate Impact of Black Carbon Emitted from Energy Consumption in the World's Regions, Geophys. Res. Lett., 34, L11802, doi:10.1029/2006GL208904, 2006.

Reisinger, A., Meinshausen, M., Manning, M., and Bodeker, G.: Uncertainties of global warming metrics: $\mathrm{CO}_{2}$ and $\mathrm{CH}_{4}$, Geophys. Res. Lett., 37(14), L14707, doi:10.1029/2010GL043803, 2010.

Robinson, A. L., Donahue, N. M., Shrivastava, M. K., Weitkamp, E. A., Sage, A. M., Grieshop, A. P., Lane, T. E., Pierce, J. R., and Pandis, S. N.: Rethinking Organic Aerosols: Semivolatile Emissions and Photochemical Aging, Science, 315, 1259-1262, doi:10.1126/science.1133061, 2007.

Shine, K., Fuglestvedt, J., Hailemariam, K., and Stuber, N.: Alternatives to the Global Warming Potential for Comparing Climate Impacts of Emissions of Greenhouse Gases, Clim. Change, 68, 281-302, 2005.

Somanathan, S., Flynn, P. C., and Szymanski, J.: The Northwest Passage: A Simulation, Transp. Res. Part A, 43, 127-135, 2009.

Verny, J. and Grigentin, C.: Container Shipping on the Northern Sea Route, Int. J. Prod. Econom., 122(1), 107-117, doi:10.1016/j.ijpe.2009.1003.1018, 2009.

Wang, C., Corbett, J. J., and Firestone, J.: Improving Spatial Representation of Global Ship Emissions Inventories, Environ. Sci. Technol., 42, 193-199, 2008.

Winebrake, J. J., Corbett, J. J., and Green, E. H.: Black Carbon Control Costs in Shipping, ClimateWorks, Pittsford, NY, USA, 14 pp., 2009a.

Winebrake, J. J., Corbett, J. J., Green, E. H., Lauer, A., and Eyring, 
V.: Mitigating the Health Impacts of Pollution from Oceangoing Shipping: An Assessment of Low-Sulfur Fuel Mandates, Environ. Sci. Technol., 43, 4776-4782, doi:10.1021/es803224q, 2009b. 